\title{
ENVIRONMENTAL AND CLIMATE
}

TECHNOLOGIES

ISSN 1691-5208

VIDES UN KLIMATA

TEHNOLOĢIJAS

2009-5208

10.2478/v10145-009-0012-9

LIFE CYCLE ASSESMENT OF DAUGAVGRIVA WASTE WATER TREATMENT PLANT

DAUGAVGRĪVAS NOTEKŪDEŅU ATTĪRĪŠANAS IEKĀRTU DZīVES CIKLA ANALĪZE

F. Romagnoli, Master of Science, resercher

Riga Technical University, Institute of Energy Systems and Environment

Address: Kronvalda Bulvaris, LV-1010, Riga, Latvia

Phone: +371 28354151, Fax: +371 67089908

e-mail: francesco.romagnoli@,rtu.lv

F. Fraga Sampaio, Master of Science

Riga Technical University, Institute of Energy Systems and Environment Address: Kronvalda Bulvaris, LV-1010, Riga, Latvia

e-mail: felipefraga27@yahoo.com.br

D. Blumberga, Dr.hab.sc.ing,

Riga Technical University, Institute of energy systems and environment Adress: Kronvalda boulevard 1, LV-1010, Riga, Latvia

Phone.: +371 7089908, Fax: +371 7089908

e-mail: dagnija.blumberga@rtu.lv 


\section{Introduction}

Riga presents a population of approximately 747 thousand people and only one waste water treatment plant (WWTP) is responsible for the whole treatment of the area of the city: the Daugavgriva plant [1].

The life cycle assessment (LCA) is a good tool to assess and evaluate (qualitatively and quantitatively) the impact of a process that most seriously affects the environment. In this paper this type of analysis seems to be really effective for the evaluation of the impact caused by the WWTP of Daugavgriva.

In following the principal aims of this paper are described:

- to collect comprehensive life cycle inventory data of the total WWTP system (from the source to the land filled place);

- to conduct the life cycle impact assessment (LCIA);

- to provide consistent data useful for decisionmakers.

\section{Background}

In Baltic countries and Poland [2], research shows that more than $65 \%$ of the population in Estonia, Latvia and Lithuania is connected to the waste water treatment while in Poland less than $60 \%$. Waste Water Treatment (WWT) in all parts of Europe has improved during the last 15-20 years and consequently the number of people connected to WWT has also risen even if some regions show lacks of appropriate treatment. The increasing regulation concerning the environmental impact makes the analysis of WWT processes an extreme important and actual hot topic [3].

\section{Daugavgriva Waste water treatment plant description}

The WWT technologies, utilized also in the plant of Daugavgriva, could be divided into three different general methods: physical, chemical and biological methods.

Physical method involves two solid-liquid separation groups of technologies regarding filtration and sedimentation.

Chemical method is identified by the addiction of chemicals in the process in an attempt to remove, reduce, neutralize or destroy the waste water contaminants through chemical reactions.

Biological method is based on the removal of the contaminants by biological means.

The plant of Daugavgriva consists mainly of six steps [4]:

1) Pre-treatment,

2) Physical and mechanical treatment or primary treatment,

3) Secondary treatment or biological treatment,

4) Tertiary or complementary treatment,

5) Sludge treatment

6) Sludge disposal

The WWT system in Daugavgriva is described into the figure 1.

\section{Methane production}

In the anaerobic digestion process the volatile content of the sludge from the first sedimentation together with the excess sludge recycled from the secondary treatment is biologically converted in absence of oxygen in methane $\left(\mathrm{CH}_{4}\right)$ and carbon dioxide $\left(\mathrm{CO}_{2}\right)$. Methane is formed by a major route that comes from the fermentation of the major product of acid forming phase (acetic acid) to $\mathrm{CH}_{4}$ and carbon dioxide $\left(\mathrm{CO}_{2}\right)$. The overall reaction is shown in Equation 2:

$$
\mathrm{CH}_{3} \mathrm{COOH}_{(a q)} \rightarrow \mathrm{CH}_{4(g)}+\mathrm{CO}_{2(g)}
$$




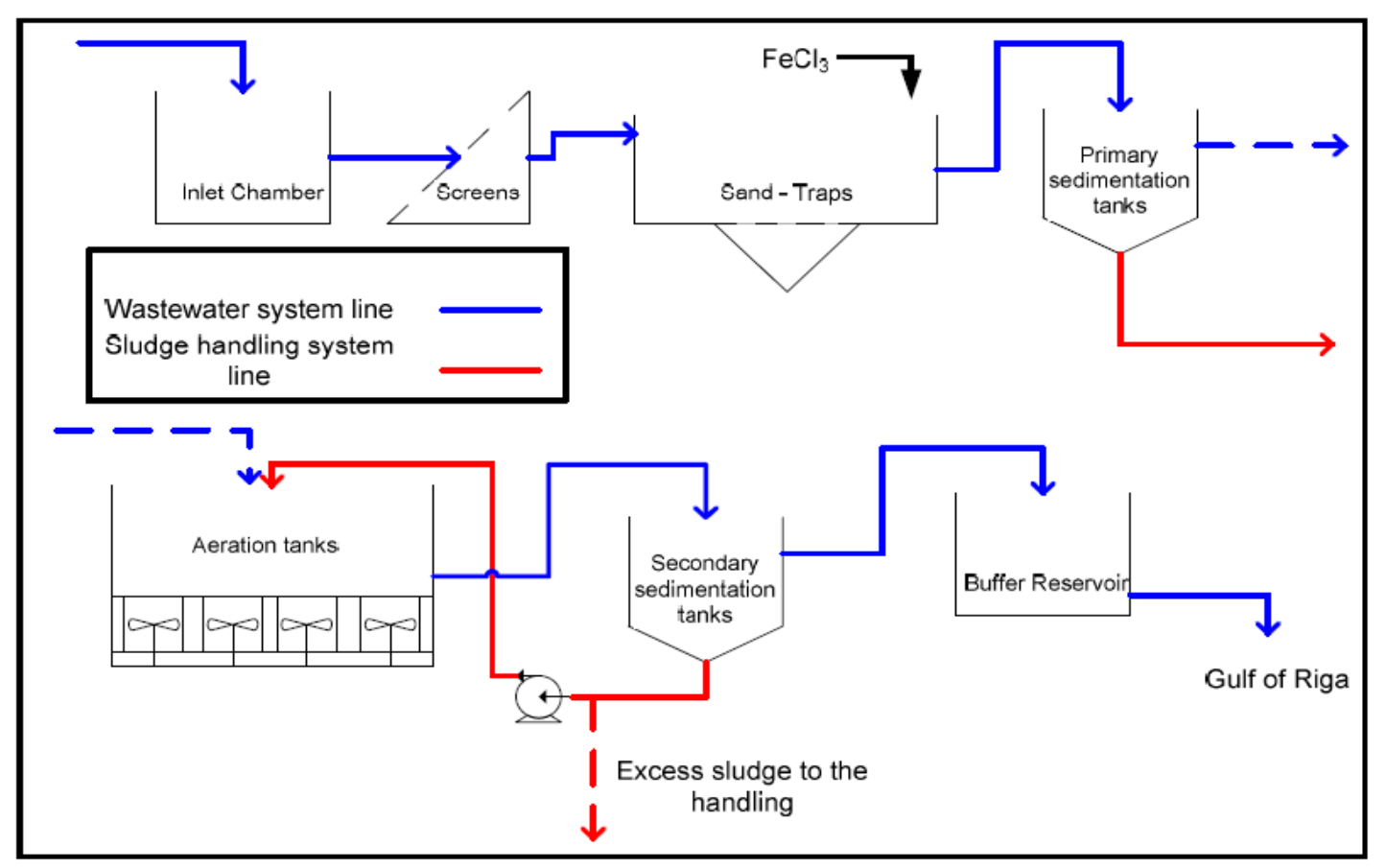

Fig.1. Waste water treatment system scheme of Daugavgriva WWTP

In Daugavgriva plant methane is the final gas that is used to supply a cogeneration plant. The quantity of methane gas produced can be computed by the Equation 3 [6].

$$
V=350\left[Q\left(S_{0}-S\right) /(1000)-1.42 P_{\mathrm{x}}\right]
$$

Where:

$V=$ volume of methane produced at standard conditions $\left(0^{\circ} \mathrm{C}\right.$ and $\left.1 \mathrm{~atm}\right), \mathrm{L} / \mathrm{d}$;

$350=$ theoretical conversion factor for the amount of methane produced per $\mathrm{kg}$ of ultimate;

BOD oxidized, $350 \mathrm{~L} / \mathrm{kg}$;

$1000=1000 \mathrm{~g} / \mathrm{kg}$;

$Q=$ flow rate, $\mathrm{m}^{3} / \mathrm{d}$;

$S_{0}=$ influent ultimate BOD, $\mathrm{mg} / \mathrm{L}$

$S=$ effluent ultimate $\mathrm{BOD}, \mathrm{mg} / \mathrm{L}$;

$P \mathrm{x}=$ net mass of cell tissue produced, $\mathrm{kg} / \mathrm{d}$.

For a complete-mix high-rate anaerobic digester without recycle, the mass of biological solids synthesized daily, $\mathrm{P}_{\mathrm{x}}$, can be estimated by the Equation 4:

$$
P_{x}=\frac{Y\left[Q\left(S_{0}-S\right)\right]}{1+k_{d} \theta_{c}}
$$

Where:

$\mathrm{Y}=$ yield coefficient, $\mathrm{kg} / \mathrm{kg}$;

$\mathrm{kd}=$ endogenous coefficient, per day;

$\theta \mathrm{c}=$ mean cell residence time, $\mathrm{d}$;

\section{CHP plant}

The cogeneration plant in Daugavgriva WWTP consumes per day all the biogas produced (around $13.000 \mathrm{~m}^{3}$ ) and another amount of natural gas (around $7.500 \mathrm{~m}^{3}$ ). Two boilers are used for the production of steam. The scheme of the plant is showed in the reference [7]. The cogeneration plant presents an average efficiency of $75 \%$ with a production around 2,2 MW of electricity per day and $2440 \mathrm{MW}$ of heating. The production of biogas is not enough to supply the whole demand of energy of the plant processes. The plant spends about 1,2 MW per day of electricity and basically all the heating energy produced is used in the process (digesters) and households.

The energy production is divided between the biogas and natural gas as reported in the following [7]:

Electrical energy produced:

- Biogas =1,048 MW

- Natural gas $=0,976 \mathrm{MW}$

Heat energy:

- Biogas =1263 MW

- Natural gas $=1185 \mathrm{MW}$

\section{Initial data}

In this study official data from year 2008 was used (see table 1). 
Wastewater quality in Daugavgriva WWTP in 2008

Table 1.

\begin{tabular}{|c|c|c|}
\hline Item & Effluent & Reduction, \% \\
\hline BOD5, $\mathrm{mg} \mathrm{O}_{2} / 1$ & 17,12 & 93,6 \\
\hline Nitrogen, $\mathrm{mg} / \mathrm{l}$ & 39,41 & 24,1 \\
\hline Phosphorus, mg/l & 2.90 & 63,2 \\
\hline $\mathrm{COD}, \mathrm{mg} / \mathrm{l}$ & 77,58 & 87,3 \\
\hline
\end{tabular}

The data collected were also based on information given by the WWTP technical personal, visits, interview and official data provided from related environmental institutions [7].

\section{Life cycle assessment (LCA)}

In this work, an LCA using CML 2000 methodology (developed by the Centre of Environmental Studies of the University of Leiden) is carried out.

Goal and scope. The goal of the LCA is to identify and assess the main impacts caused by the treatment processes. The study was focused on the environmental impact categories that contribute more than one per cent of the total impact. Impacts on land use and land competition will not be considered in this study. Also the construction phase of the plant and materials will not be included in this paper due to lack of data.
Boundary. Due to the complexity of the total waste water treatment and the impossibility to obtain data, the boundary of this study is set in the point where raw waste water is received in the inlet tank in the WWTP until the point where it is treated and ready to discharge $5 \mathrm{~km}$ from the WWTP in the gulf of Riga. The WWTP also has a sludge handling system and a cogeneration plant which were included in the LCA study.

The Figure 5 shows a short flowchart of the process and the study's boundary.

The functional unity (fu) chosen for this study is the total amount of treated waste water per year. As showed in the Figure 2 the results will be presented for four different unit processes identified in the plant treatment: waste water treatment, sludge handling system, cogeneration plant and waste disposal.

Data for the amount and characteristics of waste water, chemicals used, biogas produced, total energy spent and produced, and amount of solid waste generated were collected in the plant by personal interview. The main inventory data are shown in the Table 2 .

Inventory (quantity per year)

Table 2.

\begin{tabular}{|c|c|c|c|c|}
\hline & Constituent & Value & Unity & Comments \\
\hline \multirow{10}{*}{ 흘 } & Raw wastewater & 57.908 .396 & $\mathrm{~m}^{3}$ & \\
\hline & \multicolumn{4}{|l|}{ Chemicals } \\
\hline & Ferric Chloride & 1.576 .800 & $\mathrm{~kg}$ & Used in the primary treat. \\
\hline & Organic Polymer & $45.807,5$ & $\mathrm{~kg}$ & Used in the sludge treat. \\
\hline & \multicolumn{4}{|l|}{ Energy } \\
\hline & Electricity & 10.512 & MW & Households and process \\
\hline & Heat & 21.445 & MW & Households and process \\
\hline & \multicolumn{4}{|l|}{ Resources } \\
\hline & Natural gas & 2.737 .500 & $\mathrm{~m}^{3}$ & Used in the cogeneration \\
\hline & Fossil fuel & 1.119 .382 & MJ & Solid waste transportation \\
\hline \multirow{8}{*}{ 홓 } & Treated wastewater & 57.889 .000 & $\mathrm{~m}^{3}$ & $\begin{array}{l}\text { Part of the water } \\
\text { incorporates within the } \\
\text { sludge. }\end{array}$ \\
\hline & \multicolumn{4}{|l|}{ Energy } \\
\hline & Electricity & $9.180,5$ & MW & Produced by biogas \\
\hline & Heat & 10.381 & MW & Produced by biogas \\
\hline & Air emissions & 26.352 .617 & $\mathrm{~kg}$ & All amount of air emission \\
\hline & \multicolumn{4}{|l|}{ Solid waste } \\
\hline & Sludge & 70.000 & $\mathrm{~kg}$ & $\begin{array}{l}23 \% \text { dry solids. To municipal } \\
\text { landfill. }\end{array}$ \\
\hline & Grit + Screen & 12.000 & $\mathrm{~kg}$ & To municipal landfill. \\
\hline
\end{tabular}




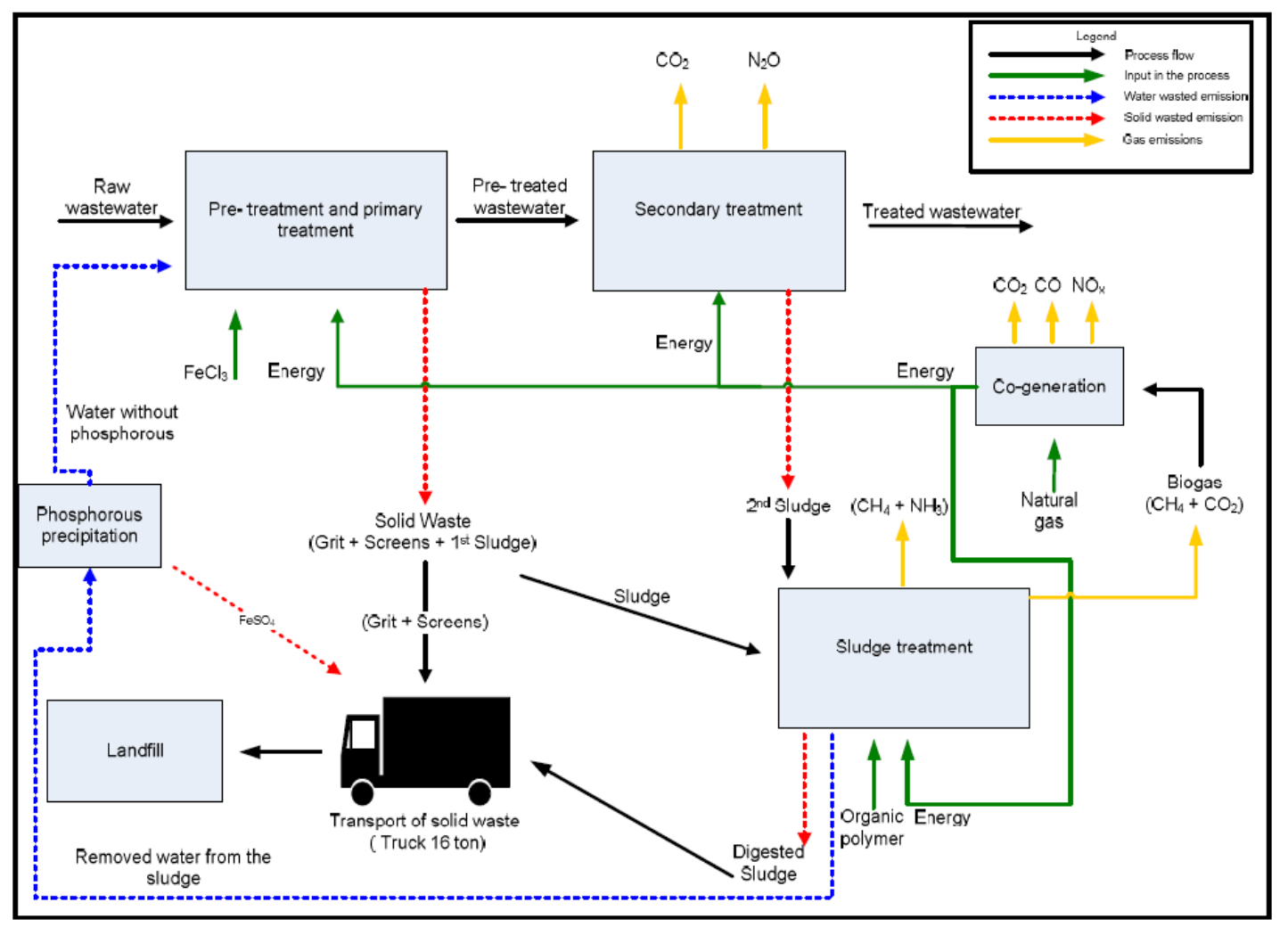

Fig. 2. LCA system boundary

During the data collection due to lack of direct information the following data were assumed and/or estimated:

- Air emissions estimated by [10,11, 12 and 13];

- sludge composition estimated according to [6] and [14];

- transportation to landfill assumed by 16 ton trucks;

- assumption of distance of $20 \mathrm{~km}$ from the WWTP until the landfill;

- characteristics of contaminants in waste water influent from [8] and [9].

LCA Assumptions. In order to finalize the present study during the LCA the list of the assumptions described below was taken into account:

- neglection of methane emissions from the anaerobic part of the activated sludge tanks (due to lack of data);

- neglection of the construction phase and materials for the unit operations in the plant;

- sludge composition and final distance to landfill were estimated due to impossibility to obtain the data [6] [14];

- transportation of chemicals used in the process not included; although partial data for abiotic depletion of resources in the production of these materials were taken into account;

- the phosphorus precipitation stage after the water from the dewatering sludge unit process was neglected due to lack of information; - only biogas and ammonia losses accounted;

LCIA. The impact categories considered in this study are: abiotic depletion, climate change, ozone layer depletion, ozone layer, photochemical oxidation, human toxicity, terrestrial ecotoxicity, fresh water ecotoxicity, marine ecotoxicity, eutrophication and acidification.

After the calculation of the emissions, those values were set into impact categories and characterized by the use of the characterization factors with the final purpose to give an equivalent impact for each categories. Later, the equivalent value was divided by the normalized factor giving the normalized values.

In the Table 3 are summarized the main emissions for each unit process of the plant that, in reference to the impact categories, give a contribution bigger than one percent of the total impact. In the last column a quality of the data used is described. 
Table 3.

List of the emissions for all the impact categories (contribution bigger than $1 \%$ of the total impact)

\begin{tabular}{|c|c|c|c|c|}
\hline 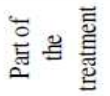 & Impact Category & Compounds & $\begin{array}{l}\text { Amount }(\mathrm{kg}) \\
\text { per function } \\
\text { unity }\end{array}$ & $\begin{array}{l}\text { Quality } \\
\text { of the } \\
\text { data }\end{array}$ \\
\hline \multirow{7}{*}{ 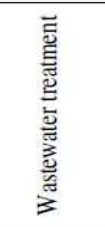 } & Abiotic Resource depletion & Chlorine & $1.034 .045,00$ & Good \\
\hline & Abiotic Resource depletion & Iron Ore & $542.390,00$ & Good \\
\hline & Climate change & $\mathrm{CO}_{2}$ & $10.311 .202,55$ & Medium \\
\hline & Climate change & $\mathrm{N}_{2} \mathrm{O}$ & $120.100,00$ & Medium \\
\hline & Eutrophication & COD & $4.492 .549,00$ & Good \\
\hline & Eutrophication & T- P & $167.886,00$ & Good \\
\hline & Eutrophication & T- N & $2.282 .105,00$ & Good \\
\hline \multirow{3}{*}{ 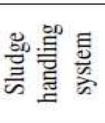 } & $\begin{array}{l}\text { Climate change/ Photo- } \\
\text { oxidant formation }\end{array}$ & $\mathrm{CH}_{4}$ & $185.000,00$ & Bad \\
\hline & Climate change & $\mathrm{CO}_{2}$ & $99.645,00$ & Bad \\
\hline & Acidification / Eutrofication & $\mathrm{NH}_{3}$ & $12.866,06$ & Bad \\
\hline \multirow{8}{*}{ 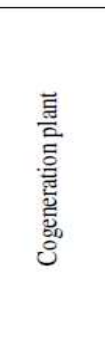 } & Abiotic Resource depletion & $\begin{array}{c}\text { Natural gas } \\
\left(\mathrm{m}^{3}\right)\end{array}$ & $2.737 .500,00$ & Good \\
\hline & Climate change & $\mathrm{CO}_{2}$ & $15.323 .550,00$ & Medium \\
\hline & $\begin{array}{c}\text { Climate change/ Photo- } \\
\text { oxidant formation }\end{array}$ & $\mathrm{CH}_{4}$ & $87.086,10$ & Medium \\
\hline & Climate change & $\mathrm{N}_{2} \mathrm{O}$ & 183,6 & Medium \\
\hline & $\begin{array}{l}\text { Acidification / Eutrofication/ } \\
\text { Photo-oxidant formation }\end{array}$ & $\mathrm{NO}_{\mathrm{x}}$ & $76.474,80$ & Medium \\
\hline & Photo-oxidant formation & $\mathrm{CO}$ & $47.538,33$ & Medium \\
\hline & $\begin{array}{l}\text { Photo-oxidant formation / } \\
\text { Acidification }\end{array}$ & $\mathrm{SO}_{2}$ & $2.108,24$ & Medium \\
\hline & Photo-oxidant formation & Formaldehyde & $4.712,00$ & Medium \\
\hline \multirow{3}{*}{ 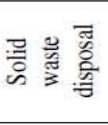 } & Abiotic Resource depletion & $\begin{array}{c}\text { Fossil energy } \\
(\mathrm{MJ})\end{array}$ & $1.119 .382,00$ & Medium \\
\hline & Climate change & $\mathrm{CO}_{2}$ & $81.431,50$ & Medium \\
\hline & Acidification / Eutrofication & $\mathrm{NO}_{\mathrm{x}}$ & 719,05 & Medium \\
\hline
\end{tabular}

\section{Results}

In the following figure it is reported the amount of emission for each impact categories after the characterization of the emission values. This provides a first idea of the amount of equivalent pollutants emitted by each impact category.

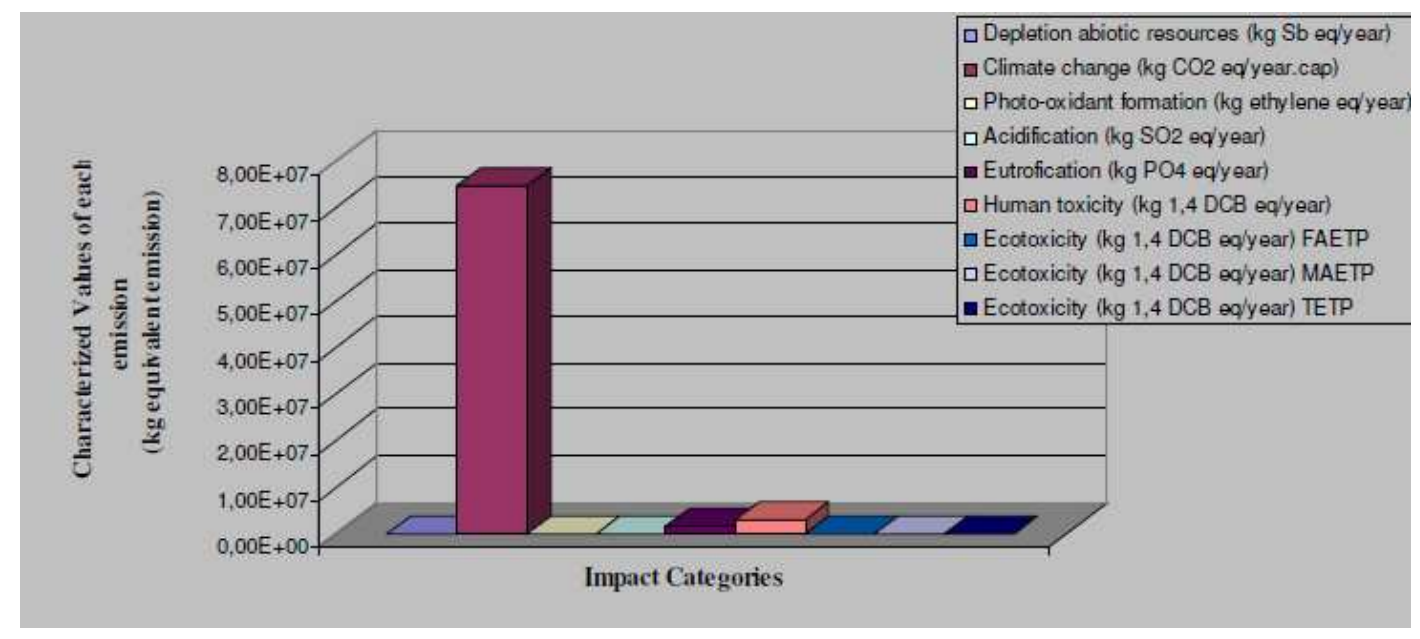

Fig. 3: Environmental Profile - Equivalent emissions for values not normalized

Three categories showed to have significant amount of equivalent pollutant emissions: climate change, human toxicity and eutrophication.

As can be seen the climate change represents the biggest amount (mass) of pollutant emitting 7,15 x 10 $\mathrm{kgCO}_{2 \text { eq }}$ per functional unit.
The results for the normalized values are described in Figure 4. 


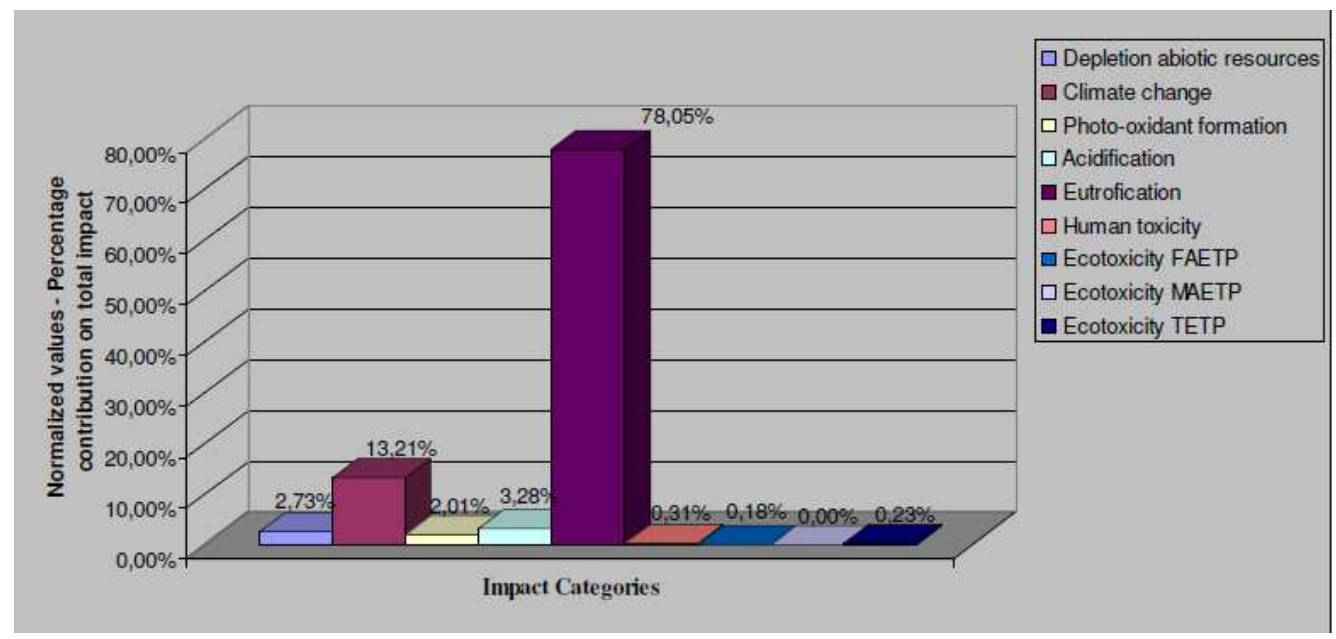

Fig. 4. LCIA results after normalization

The results achieved after the normalization, show clearly that the impact category contributing the most for the total impact in the overall environmental profile is eutrophication followed by climate change, acidification and depletion of abiotic resources. The other impact categories showed to have minimal effect in the total impact.

\section{Analysis of results}

The analysis has been focused only on the impact categories that contribute more than $1 \%$ respect the total impact, a summary table is showed in the following Table 4 . The last column shows the benefit from the use of biogas for each impact category.

Table 4.

Contribution and benefit values relative to the total impact for each category

\begin{tabular}{|l|l|r|r|r|}
\hline \multicolumn{1}{|c|}{ Groups } & \multicolumn{1}{|c|}{ Impact categories } & $\begin{array}{c}\text { Normalized } \\
\text { values }\end{array}$ & $\begin{array}{c}\text { Total impact } \\
\text { contribution }\end{array}$ & $\begin{array}{c}\text { Benefit yielded by } \\
\text { the biogas }\end{array}$ \\
\hline Resources & Depletion abiotic resources & $3,06 \times 10^{-06}$ & $2,73 \%$ & $3,05 \%$ \\
\hline Human health & Human toxicity & $3,38 \times 10^{-7}$ & $0,31 \%$ & $0,00 \%$ \\
\hline Ecological & Climate change & $1,48 \times 10^{-5}$ & $13,21 \%$ & $1,46 \%$ \\
\cline { 2 - 5 } & Photo-oxidant formation & $2,26 \times 10^{-06}$ & $2,01 \%$ & $0,73 \%$ \\
\cline { 2 - 5 } & Acidification & $3,67 \times 10^{-06}$ & $3,28 \%$ & $0,50 \%$ \\
\cline { 2 - 5 } & Eutrofication & $8,75 \times 10^{-5}$ & $78,05 \%$ & $0,12 \%$ \\
\cline { 2 - 5 } & Ecotoxicity FAETP & $2,06 \times 10^{-7}$ & $0,18 \%$ & $0,04 \%$ \\
\cline { 2 - 5 } & Ecotoxicity MAETP & $5,27 \times 10^{-10}$ & $0,00 \%$ & $0,00 \%$ \\
\cline { 2 - 5 } & Ecotoxicity TETP & $2,56 \times 10^{-7}$ & $0,23 \%$ & $0,02 \%$ \\
\hline Total & $1,12 \times 10^{-4}$ & $100 \%$ & $5,91 \%$ \\
\hline
\end{tabular}

From the previous table it can be seen that only five impact categories contribute more than

$1 \%$ respect to the total impact. It is evident how the cogeneration plant with the use of biogas instead of fossil fuel gives environmental benefits in all categories analyzed.

Eutrophication. Figure 5 describes the contribution to the single impact category for each stage of the plant respect to the total impact. 


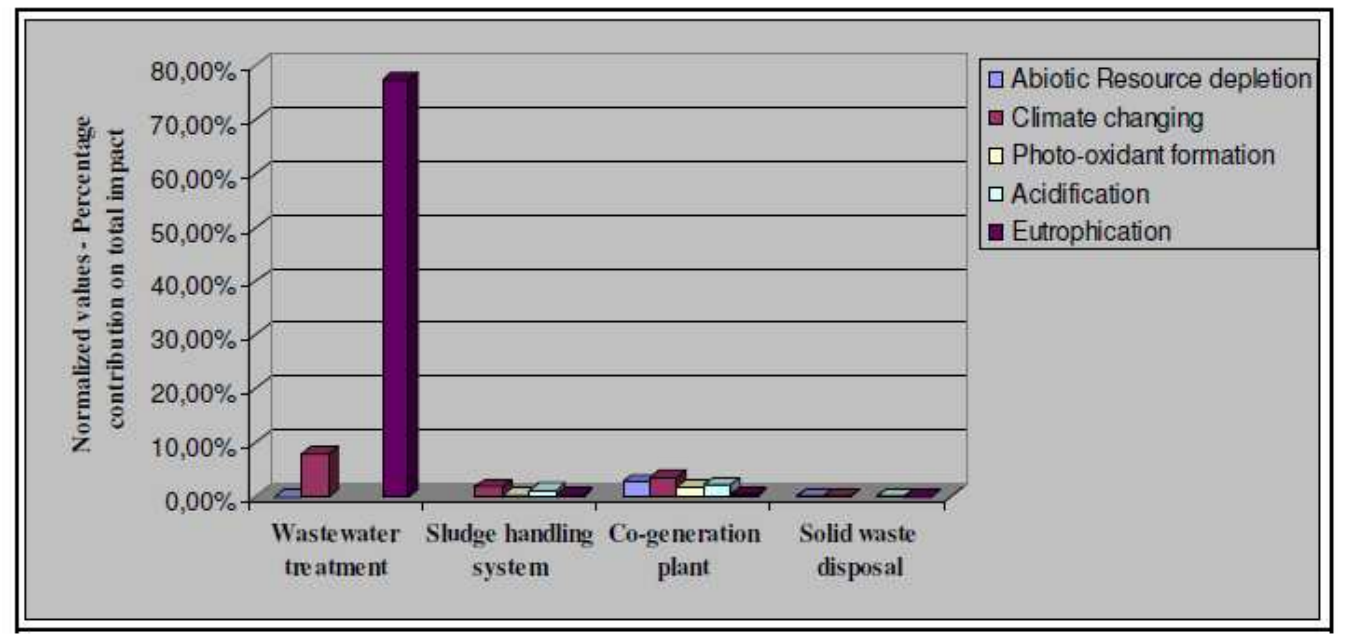

Fig. 5. LCIA results after normalization accounted for each stage of the WWTP for categories contributing more than $1 \%$ in the total impact

The result shows that $78,05 \%$ of the total impact comes from eutrophication and the main contribution is associated to the waste water treatment stage. Pollutants responsible for causing eutrophication in this stage are nitrogen, phosphorus and chemical oxygen demand.

Figure 6 shows the distribution for the eutrophication impact through the whole process stages. The emission of ammonia comes from the digested sludge degasification and NOx emissions from the cogeneration plant and transportation.

The benefit for the eutrophication category comes from the avoided emissions of NOx by the utilization of biogas instead of other fossil fuel. The benefits are equal to $0,12 \%$ of the total environmental impact.

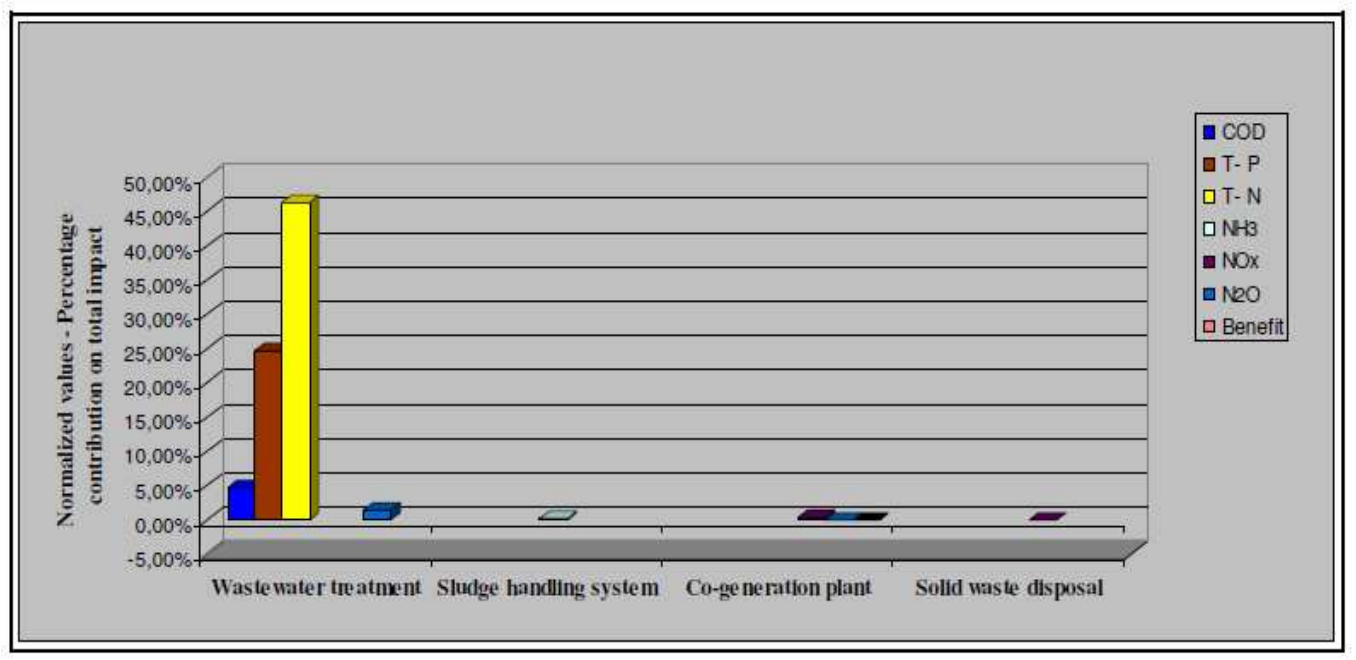

Fig. 6. LCIA results after normalization for eutrophication divided in stages

Climate Change. The three green house gases (GHG), naturally produced in the plant, that contribute for global warming are: $\mathrm{CH}_{4}, \mathrm{CO}_{2}$ and $\mathrm{N}_{2} \mathrm{O}$. Also the burning of natural gas and biogas in the cogeneration plant and transportation to the landfill contribute for the emission of GHG.

$\mathrm{N}_{2} \mathrm{O}$ produced in the activate sludge tanks in the waste water treatment is the biggest contributor for the climate change. $\mathrm{N}_{2} \mathrm{O}$ has a 280 times stronger effect than $\mathrm{CO}_{2}$ [17].
$\mathrm{N} 2 \mathrm{O}$ represents a significant factor of $26 \%$ in the greenhouse gas footprint of the total water

chain. Moreover there is an increasing need to reduce these emissions and to identify the factors that control the GHG emissions from WWTPs [17].

If the emissions in the waste water treatment stage are not taken into account the main contribution comes from the leakage of methane in the sludge handling system and from the burning of fuel in the cogeneration plant. Figure 7 below shows the distribution of the impact. 


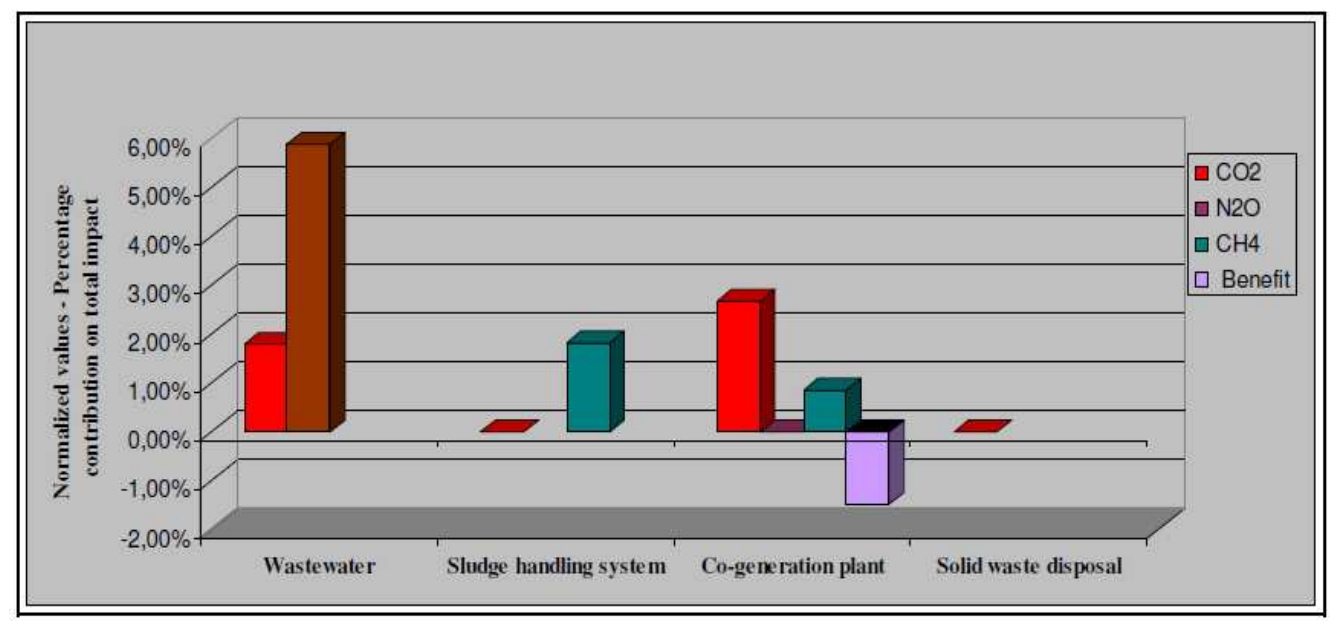

Fig. 7. LCIA results after normalization for climate change

The avoided emissions of $\mathrm{CO}_{2}, \mathrm{CH}_{4}$ and $\mathrm{N}_{2} \mathrm{O}$ are equal to the $1,48 \%$ of the total impact in terms of process benefit.

Acidification. The burning of the biogas and natural gas in the cogeneration plant contribute to the acidification category emitting nitrogen oxides and sulphur oxides followed by gaseous ammonia emissions in the sludge handling system. The uncertainty about the ammonia emissions into the air treatment makes difficult the analysis.

The acidification distribution among all the plant stages is showed in the Figure 8. The benefit for this impact category is due to emissions of $\mathrm{NO}_{\mathrm{x}}$ avoided for a quantity equal to $0,51 \%$ of the total impact.

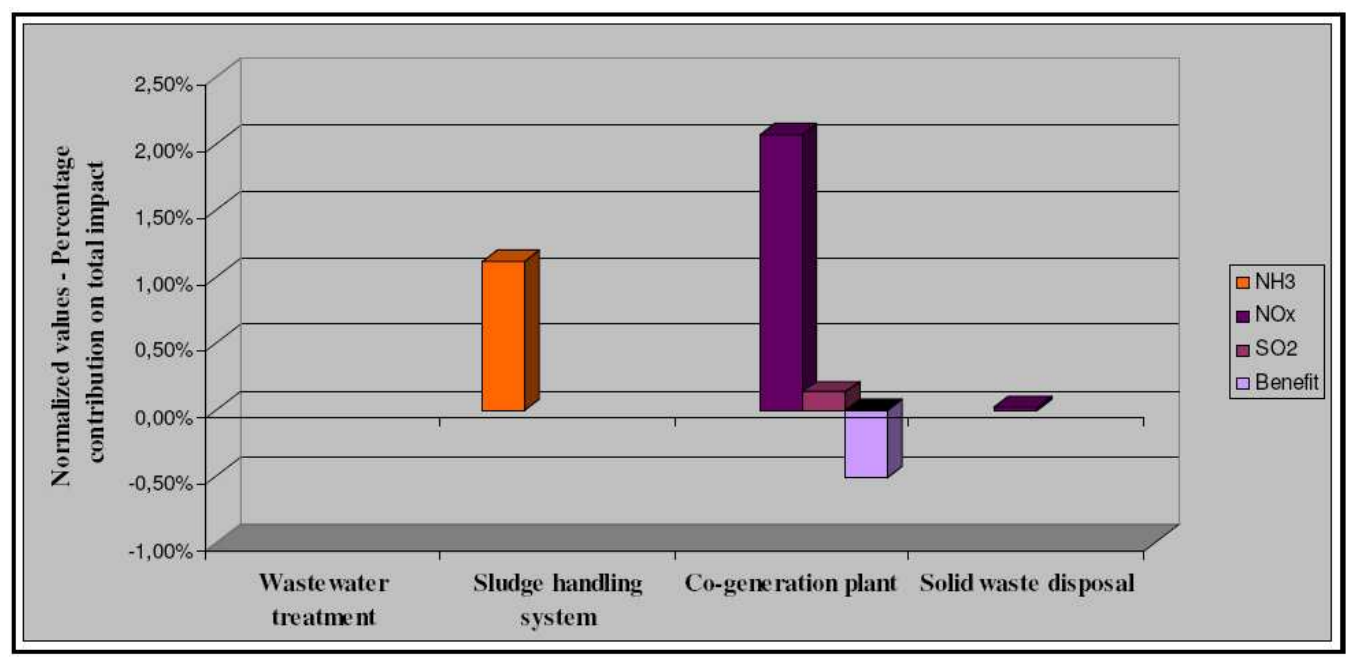

Fig. 8. LCIA results after normalization for acidification

Abiotic resources depletion. Natural gas consumed in the cogeneration plant, is by far the biggest contributor for depletion of the abiotic resources.
The benefit of this category accounts for $3,11 \%$ of the total impact due to avoidance of natural gas depletion. The Figure 9 displays the abiotic depletion through the stages. 


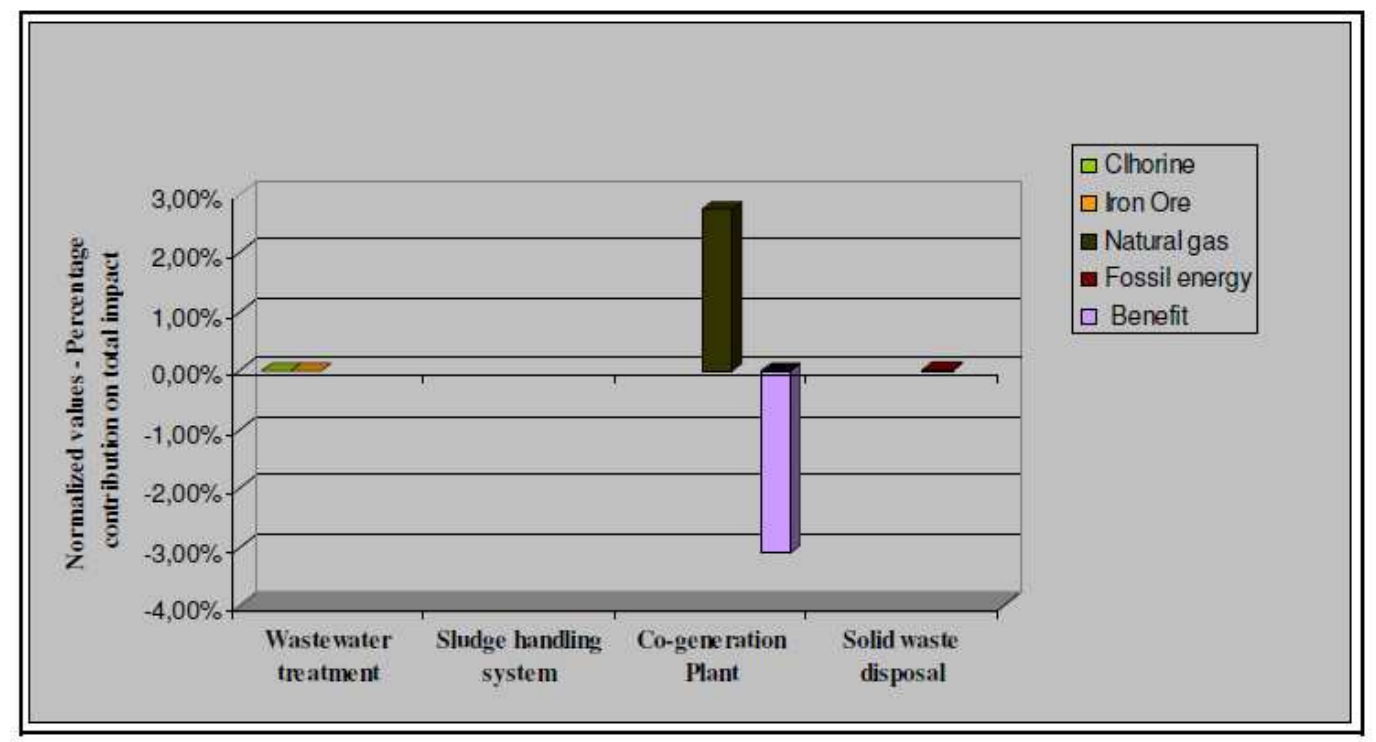

Fig. 9. LCIA results after normalization for abiotic resource depletion

Photo-oxidant Formation. The photo-oxidant formation impact category contributes $2,05 \%$ respect to the total impact. The biggest contribution comes from the cogeneration plant having formaldehyde and nitrous oxide as principal pollutant. In the sludge handling system, methane leakage has also a significant contribution in this impact category. In the following Figure 10 the contribution of $\mathrm{NO}$ emissions (is included in the total amount of $\mathrm{NOx}$ emitted.

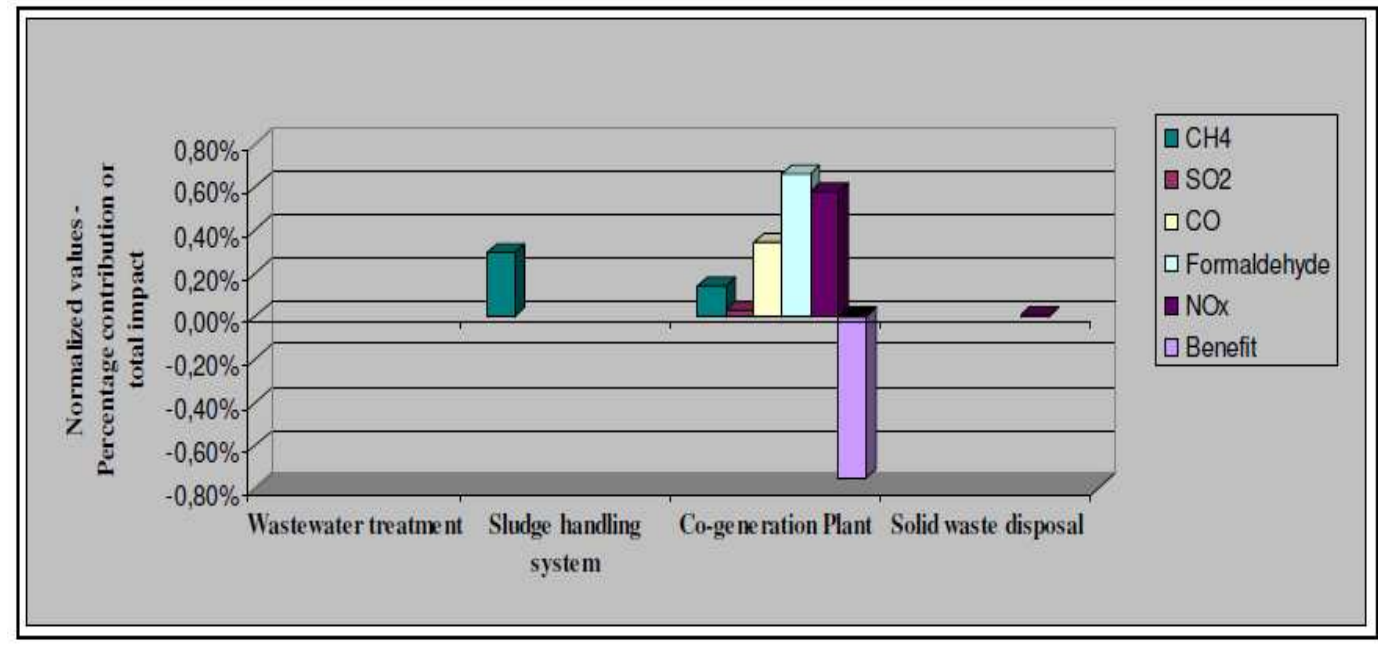

Fig. 10. LCIA results after normalization for photo-oxidant formation

LCA Conclusions. The results performed by LCIA clearly show that the impact category contributing the most to the total impact comes from the waste water treatment stage relative to the eutrophication impact category. The pollutant emitted is total nitrogen which consists of organic and inorganic forms of nitrogen. Phosphorus also plays a significant part to eutrophication.

Climate change analysis has demonstrated that an important impact came also from the waste water treatment stage where $\mathrm{N}_{2} \mathrm{O}$ is the major pollutant.
Acidification, abiotic depletion and photo-oxidant formation showed low contributions for the total environmental impact.

NOx is the biggest contributor for the acidification. The emission of Nox is mainly associated to cogeneration plant in particularly with the burning of the natural gas and biogas. The engine burning biogas is responsible for the biggest part of the NOx emitted due to the high amount of nitrogen in the biogas composition.

The abiotic depletion shows that natural gas consumed in the cogeneration plant contributes the most part but of course the utilization of biogas avoids the depletion 
of more natural gas giving a positive environmental benefit.

Due to lack of measurements and/or information, general uncertainties and limited data the results provided in this paper need futher analyses.

\section{References}

1. Central Statistical Bureau of Latvia, 2002. // http://www.csb.gov.lv/[20.04.2009].

2. European Environmental Agency. CSI 024 - Urban waste water treatment - Assessment published Jan 2009.

3. Kirk B. and Al. Methods for Comparison of Wastewater Treatment Options. Prepared for the National Decentralized Water Resources Capacity Development Project. - Washington University, St. Louis, USA, 2005.

4. Rydén L. and Al. . Environmental Sciences. -The Baltic University Press; Uppsala, 2003.

5. Cheremisinoff N. P. Handbook of water and wastewater treatment technologies. - Boston, United States of America, 2002.

6. Droste R. L. Theory and practice of water and wastewater treatment. - United States of America and Canada. 1997.

7. Inventory data acquired from the Daugavgriva WWTP in April 2009.

8. Actions to limit emissions and discharges of nutrients from land based sources // Helsinki Commission. Land-based Pollution Group 13th Meeting. Kaliningrad, Russia19, May 2008.

9. Halla T. Water management in Riga and in Copenhagen. The Sea and the Cities project. University of Helsinki, Finland, 2000.

10. Nielsen and Al.. Emission Factors for gas fired CHP Units $<25$ MW. - National Environmental Research Institute. Roskilde, Denmark, 2004.

11. Cuéllar A. D. et Al. Cow power: the energy and emissions benefits of converting manure to biogas. - Department of Chemical Engineering, The University of Texas at Austin, USA, 2008.

12. Rochas M. Analysis of Mechanisms for $\mathrm{CO}_{2}$ Emission Reduction in Latvian Energy Installations. - RTU EEF, Riga, 2006.

13. Weiland P. Impact of competition claims for food and energy on German biogas production. Johann Heinrich von Thünen-Institute. Federal Research Institute for Rural Areas, Forestry and Fisheries. Braunschweig, Germany, 2008.

14. Metcalf \& Eddy Inc. Wastewater engineering: Treatment, disposal and reuse. - United States of America. 1979.

15. Lee C. C., Lin S. D. Handbook of Environmental Engineering Calculations. 2nd edition. - United States, McGraw-Hill Companies, 2007.
16. Rochas M. Analysis of Mechanisms for $\mathrm{CO}_{2}$ Emission Reduction in Latvian Energy Installations. - RTU-EEF, Riga, 2006.

17. Kampschreur M.J. et Al. . Nitrous oxide emission during wastewater treatment. - Dutch Foundation for Applied Sciences STW, 2009.
Francesco Romagnoli, Felipe Fraga Sampaio, Dagnija Blumberga, Daugavgrīvas notekūdeņu attīrīšanas iekārtu dzīves cikla analīze

Raksts sniedz pārskatu par notekūdeņu attīī̌šanas ietekmi uz vidi Daugavgrīvas notekūdenu attīrī̄sanas iekārtās ar biogāzes kogenerācijas staciju, kas novērtēta ar dzīves cikla analīzes palīdzību.

Dzīves cikla analīze ir piemērota metode, ar kuras palīdzību vērtēet analizēto iekārtu ietekmi uz vidi. Rezultāti parāada, $k a$ vislielāko ietekmi uz vidi rada eitrofikācija, ko lielākoties izraisa notekūdeņu apstrādes posms.

Otra nozīmīgakā ietekme, ko rada notekūdeņu apstrādes posms, ir uz klimata pārmaināam, kur nozīmīgākais piesārņotājs ir $\mathrm{N}_{2} \mathrm{O}$.

Galvenie ieguvumi videi no biogāzes izmantošanas fosilās degvielas vietā, izsakot to ar kopējās ietekmes samazinājumu, ir: - par $3.11 \%$ samazinās abiotisko resursu noplicināšanās, par $1,48 \%$ samazinās ietekme uz klimata pārmainām, par 0,12\% samazinās ietekme uz paskābināšanos un par 0,12\% ietekme uz eitroficēšanos.

Francesco Romagnoli, Felipe Fraga Sampaio, Dagnija Blumberga, Life cycle assessment of Daugavgriva waste water treatment plant

This paper presents the assessment of the environmental impacts caused by the treatment of Riga's waste water in the Daugavgriva plant with biogas energy cogeneration through the life cycle assessment (LCA).

The LCA seems to be a good tool to assess and evaluate the most serious environmental impacts of a facility

The results showed clearly that the impact category contributing the most to the total impact-eutrophicationcomes from the wastewater treatment stage. 
Climate change also seems to be a relevant impact coming from the wastewater treatment stage and the main contributor to the Climate change is $\mathrm{N}_{2} \mathrm{O}$.

The main environmental benefits, in terms of the percentages of the total impact, associated to the use of biogas instead of any other fossil fuel in the cogeneration plant are equal to: $3,11 \%$ for abiotic depletation, 1,48\% for climate change, $0,51 \%$ for acidification and 0,12\% for eutrophication.

Франческо Романьоли, Фелипе Фрага Сампаио, Дагния Блумберга, Оценка жизненного цикла станции водоочистки Daugavgriva

Эта работа представляет оценку воздействий на окружаюшую среду, вызванных обработкой сточных вод Риги на станщии Daugavgriva с помощьью когенерации на биогазе, используя оценку жизненного иүикла (LCA). LCA кажется хорошим инструментом для оценки $u$ вычисления воздействия анализируемых заводов, которые наиболее сильно влияют на окружающую среду. Результаты ясно показали, что категория воздействия, составляющая большую часть всего влияния, происходит на стадии обработки сточных вод $и$ относится к категории воздействия на эвтрофикацию. Изменение климата также показало соответствующее воздействие, появляющееся также на стадии обработки сточных вод, где $\mathrm{N}_{2} \mathrm{O}$ - главный загрязнитель. Главные экологические преимущества, в расчёте на проченть от общего воздействия, связанного $c$ использованием в когенерации биогаза вместо любого другого невозобновляемого топлива, равны: 0,12\% для эвтрофикации, 0,51\% для окисления и $3,11 \%$ для абиотического истощения. 